$A D D I N$, Volume 12, Number 1, February 2018

\title{
APPRAISING THE MODERATION INDONESIAN MUSLIMS WITH SPECIAL REFERENCE TO MUHAMMADIYAH AND NAHDLATUL ULAMA
}

\author{
Hamid Fahmy Zarkasyi \\ Universitas Darussalam Gontor, Ponorogo, East Java, Indonesia \\ hfzark@unida.gontor.ac.id
}

\section{Abstract}

Indonesia is the country that has been widely regarded as home to a moderate brand of Islam compared to the more assertive political and militant Islamic revivals that have taken place in some of Middle East countries. However, recent series of terrorist attack and the emergence of groups that are categorized as extremist and fundamentalist in Indonesia have given opposite impression. This paper is aimed at appraising the the moderation of Indonesian Muslim. The object of this study is two largest Muslim organizations namely Mubammadiyah and Nabdlatul Ulama. For this appraisal the author employs the selectively the criteria of Western scholars as well as Muslim intellectuals, since there are growing tendency of observers, intellectual and policy makers to pose certain criteria of moderation based on their own interests. General survey on those tendencies suggests that there are at least three categories of moderate definition: extremist, Western biased and Islamic criteria, each of which contain acceptable and unacceptable aspects that require further selection. It is from these acceptable criteria that the author attempts to appraise the 
moderation of Indonesian Muslims through the vision and mission of mass-organization, especially Muhammadiyah and Nabdlatul Ulama as well as their education system. The study arrive on the conclusion that based on Islamic as well as Western criteria, the majority of Indonesian Muslims or the mainstream remain moderate.

Keywords: Moderate, Tolerance, Human Right, Mubammadiyah, Nabdatul Ulama.

\section{Abstrak}

MEMPERKENALKAN MUSLIM MODERAT INDONESLA LEWATREFERENSIMUHAMMADIYAH DAN NAHDLATUL ULAMA. Indonesia adalab negara yang secara luas dianggap sebagai rumah bagi model Islam moderat dibandingkan dengan kebangkitan Islam politik. dan militan yang lebih tegas yang telah terjadi di beberapa negara Timur Tengah. Namun, rangkaian serangan teroris baru-baru ini dan munculnya kelompokkelompok yang dikategorikan sebagai ekstremis dan fundamentalis di Indonesia telah memberikan kesan yang berlawanan. Tulisan ini bertujuan untuk menilai moderasi Muslim Indonesia. Objek penelitian ini adalab dua organisasi Muslim terbesar, yaitu Mubammadiyah dan Nabdlatul Ulama. Untuk penilaian ini, penulis menggunakan kriteria para cendekiawan Barat secara selektif dan juga intelektual Muslim, karena ada kecenderungan para pengamat, intelektual, dan pembuat kebijakan untuk mengajukan kriteria tertentu dari moderasi berdasarkan kepentingan mereka sendiri. Survey umum pada kecenderungan-kecenderungan tersebut menunjukean babwa setidaknya ada tiga kategori definisi moderat: ekstrem, Barat bias, dan kriteria Islam, masing-masing mengandung aspek yang dapat diterima dan tidak dapat diterima yang memerlukan seleksi lebih lanjut. Dari kriteria yang dapat diterima inilah penulis mencoba untuk menilai moderasi Muslim Indonesia melalui visi dan misi organisasi massa, terutama Mubammadiyah dan Nabdlatul Ulama serta sistem pendidikan mereka. Studi ini sampai pada kesimpulan 
bahwa berdasarkan kriteria Islam dan Barat, mayoritas Muslim Indonesia atau arus utama tetap moderat.

Kata Kunci: Moderat, Toleran, Hak Asasi Manusia, Mubammadiyah, Nabdlatul Ulama.

\section{A. Introduction}

Indonesia is an archipelago nation, made up of 17,506 inhabited and uninhabited islands. Of these the most widely known are Sumatera, Java, Bali, Kalimantan, Maluku, Papua and Sulawesi. Historically, before the spread of Islam Indonesia was ruled by Hindu and Buddhist kingdoms, especially in South Sumatera and Java. Beginning from twelve century until twenty century, Islam was spread by the merchants and Muslim scholars in peaceful fashion. There was no record of war during the spread of Islam in the Indonesian archipelago. Now, the latest statistic data of the Indonesia Central Body of Statistic (BPS) showed that the population of Indonesia in 2010 was 237 millions, but with $1.2 \%$ growth it is estimated that in 2017 the population would grow into 256 million. The data of religious denomination shows that $88 \%$ of the population professes Islam, making it the world's fourth most populous nation and the largest Muslim country. Other religious denominations are minority: Protestant (5.7\%), Catholic (3\%), Hindu (1.8\%), Buddhist (3.4\%) and other or unspecified. Despite the fact that Muslims are majority, the Indonesian Constitution guarantees the right of religious freedom, where the minorities enjoy their freedom. With regard to the ethnic the statistic data shows that Indonesia has 490 ethnic groups such as Acehness, the Bataks, the Minangkabau of Sumatera, the Javaness, Baliness, the Bugis and Toraja of Sulawesi, all distinguished from each other by language, social structure and religious tradition. ${ }^{1}$

${ }^{1}$ The general percentage distribution is the following: Javanese $45 \%$, Sundanese $14 \%$, Madurese $7.5 \%$, coastal Malay, $7.5 \%$, others $26 \%$. 
For about a century religious and ethnic plurality create no- to say the leas-social problem. The nation has been united with a single national language, Bahasa Indonesia, and a social motto namely Bhinneka Tunggal Ika (unity in diversity). The Muslims being a majority played a significance role in preserving religious freedom and tolerance. However, in the last two decades the Muslims face unprecedented challenge in which their tolerance attitudes is not regarded as sufficient to comply the standard of moderation and could be accused of being radical in negative sense of the term. This paper attempts to appraise the moderate stance of Indonesian Muslims from the vision and mission of grass root based organization especially Muhammadiyah and Nahdlatul Ulama (NU). The standard of moderation employed in this research is examined from various definition of "moderate Muslim" of Western as well as of Muslim scholars.

\section{B. Discussion}

\section{Standard of Moderation}

Defining the meaning of moderate Muslim in recent situation is quite crucial, because the term is coined to identify the opposite traits which is radical Muslim. This implies that those who are not moderate must be accused of being radical. ${ }^{2}$ The term is now widely accepted and utilized even for political motive or understood relatively, differently by different people and its definition depends on whom you ask and what that person's (or government's) agenda is. The standard of outsiders looking into Islam and Muslims looking out from within Islam are relatively different. The outsiders, especially Western intellectuals, on the one hand, interpret

${ }^{2}$ John L. Esposito, "Moderate Muslims: a Mainstream of Modernists, Islamists, Conservatives, and Traditionalists", The American Journal of Islamic Social Sciences, Volume 22, Issue 3, Summer 2005, 12-13. 
the term moderate from their own perspectives which is based on their social, cultural and religious background that in certain extend anti-Islamic or incompatible with Islamic teaching. On the other hand Muslim scholars have no such terms as moderate, progressive, or liberal Muslim, and hence among Muslim intellectuals the term moderate Muslim is used pejoratively to refer to a Muslim who is more secular and less Islamic than the norm. ${ }^{3}$ However, there are Muslims who found the term equal to Islamic vocabulary tawassut, or wasatiyah (Middle position), yet it may not necessarily satisfy Western standard or might be deemed too Islamic. The best definition is likely refer to Islamic understanding which are parallel with that of Western and foreign definition.

Now we shall examine the discourse about moderate Muslim that prevailed among the scholars in the West and the Muslim worlds. The definition of moderate Muslim could be classified into: (a) the extreme; (b) the Western biased; (c) the Islamic definition. Herewith the explication of the three classifications.

The first which is the extreme is to be found in a blog named "muslims against shariab". This blog defines Moderate Muslims are those "who is not anti-Semitic, against caliphate, critical towards Islam, pro-democracy, regards Prophet Muhammad as not noble and worthy of emulation, proreligious freedom, pro-gender and equality, against jihad, pro Islamic reform, against Islamic supremacy, pro-secular government from religious one, pro or neutral towards Israel, pro-religious equality, no response or reaction against criticism of Islam and Prophet Muhammad, against religious clothing, against shariah, against terrorism, pro-universal

${ }^{3}$ M.A. Muqtedar Khan, "Islamic Democracy and Moderate Muslims: The Straight Path Runs through the Middle", The American Journal of Islamic Social Sciences, Volume 22, Issue 3, Summer 2005, 40. 
human right". ${ }^{4}$ Another extreme criteria of moderate Muslim that concern about the Muslim commitment on shariab is reiterated by Andrew McCarthy. In his article he states that "shariah... is not moderate. Consequently, no one who advocates shariah can be a moderate, no matter how well-meaning he may be; no matter how heartfelt may be his conviction that this is God's will...."

The above definition is not moderate whatsoever, for it is in fact, an amalgamation of liberal, racial and secular thought as well as anti-Islamic spirit. This is extremely provoking hatred and abhorrence to Islam. If this definition applied to a personality of a Muslim it would necessarily exclude Muslim from their Muslim identity. It is unimaginable for Muslim, for example, to regard the Prophet Muhammad as not noble and worthy of emulation and no response or reaction against criticism of Islam and Prophet Muhammad. It is ridiculous also for Muslim to be against shariah, for if it is so the Muslim would become, "a person who is not comfortable with his/her Islamic roots and heritage, and openly hostile to Islam, and eager to transcend all Islamic norms". "Shariah in comprehensive sense that pervades both mundane and supra-mundane affairs it is still within the ambit of moderate stance. A Muslim may support secular government, but individually he might be committed to shariah. Therefore, such an understanding of shariah cannot be reconciled with the idea of secularism that separate religion from worldly affair, or separate nature and human being from a spiritual dimension. ${ }^{7}$ Muslims

${ }^{4}$ http:/ / muslimsagainstsharia.blogspot.com/2008/01/what-ismoderate-muslim.html, seen on October 18, 2010.

${ }^{5}$ Andrew McCarthy, "Inventing Moderate Islam [incl. John Esposito]", it can't be done without confronting mainstream Islam and its sharia agenda, National Review Online, August 24, 2010.

${ }^{6}$ Louay Safi, "Reflections on Ijtihad and Moderate Islam", The American Journal of Islamic Social Sciences, Volume 22, Issue 3, Summer 2005, 91.

7 Simple and clear explanation of what Islam is all about see John L. Esposito (ed.), Islam in Asia: Religion, Politic, and Society (New York-Oxford: Oxford University Press, 1987), 11-13. 
may agree to one of the most important doctrine of secularism that is to separate religion from politic, but political activities for Muslims are part of their worship to God, and hence it is a religious duty. The real case is with the personality of Irshad Manji, ${ }^{8}$ who repudiates against all things Islamic and her views on social issues are way off-center, but so far the West regarded her as "the voice of moderation".

Another extreme definition is stated by Daniel Pipes who posits that standard setters for passing the test of moderation are those who totally reject parts of the Qur'an, such as rejection of the clear commands about inheritance (Q.S. an-Nisa' [4]: 11-14, 33, and 176), court testimony (Q.S. al-Baqarah [2]: 282), and even interest (Q.S. al-Baqarah [2]: 275-76, 278-79; Q.S. Ali Imran [3]: 130; Q.S. an-Nisa' [4]: 161; and Q.S. ar-Rum [30]: 39). ${ }^{9}$ In response to this Ubid Ullah $\mathrm{Jan}^{10}$ concludes that the standard would imply that a Muslim can never be moderate unless he "publicly rejects the Qur'an". This contradicts the Islamic teaching since in Islam condemn anyone who reject part of the Qur'an (Q.S. al-Baqarah [2]: 85) or accept the revealed books in parts (Q.S. al-Ma'idah [5]: 13-14; 2:208).

In short, the anti-shariah, Andrew's and Daniel Pipes' definition suggests that they have no moderate stance and even intolerance towards Muslims' belief. For him one who devotes his/her life to the service of Creator above all other devotion is moderate. ${ }^{11}$ Even, the practicing Muslims with

\footnotetext{
${ }^{8}$ Her renown work is The Trouble with Islam: a Muslim's Call for Reform in Her Faith (n.p.: St. Martin's Press, 2004).

${ }^{9}$ http://www.danielpipes.org/article/2226, seen on October 18, 2010.

${ }^{10}$ Abid Ullah Jan is associated with the Independent Center for Strategic Studies and Analyses, a Canadian think tank. A frequent commentator on Islam and global politics, his columns are published widely by the Muslim media.

${ }^{11}$ For this he refers to Sabih al-Bukhari, vol. 3, book 40, hadith no. 550; vol. 4, book 55, hadith no. 629; vol. 7, book 70, hadith no. 577; and vol. 8, book 76, hadith no. 470, 471, and 474; and Sabih Muslim, book 32, hadith no. 6.243. Abid Ullah Jan, "Moderate Islam: a Product of American Extremism", The American Journal of Islamic Social Sciences, Volume 22, Issue 3, 30.
} 
the zeal to voice his opposition to the injustice are classified as a moderate and not radical, whereas a devout man who fervent in all of his personal rituals but not participating in political affairs is not moderate. ${ }^{12}$ So, moderation, according to Jan is total commitment to Islam, the detail criteria of which requires further clarifications.

The second category is of Western biased definition. Graham E. Fuller clearly identifies that the moderate Muslim is a person who believe in democracy, tolerance, a non-violent approach to politics, and equitable treatment of women at the legal and social levels. The moderate is also he who believes that Islam has no role in politics, and who avoids any confrontation — even political—with Israel. ${ }^{13}$ Graham's definition explicitly emphasized Western standard that need further conceptual adjustment. The consequences of this definition is considerably dangerous, for those who live in Saudi Arabia, Brunei Darussalam, and other Muslim countries which do not apply democratic system of politic would be judged as not-moderate. Should the definition is posited based on Muslim standard and applied to everyone in the world, including the Western people, many people would failed to be called moderate. The bias would vividly visible when Muslim moderate criteria refer to the humanitarian support to the independence of Palestine, tolerance towards Islamic marriage system and Muslim women dress, appreciate the Muslim political aspiration and respect humanity without discrimination of race and religion.

Another biased definition asserted by Ariel Cohen who defines moderate Muslims as one who is against violence or declining the "greater jihad" as a pillar of faith, decry

${ }^{12}$ Abid Ullah Jan, "Moderate Islam”, 30.

${ }^{13}$ Graham E. Fuller, "Freedom and Security: Necessary Conditions for Moderation", The American Journal of Islamic Social Sciences, Volume 22, Issue 3, 21-22. 
suicide bombings and terrorist "operations". The example of moderate Sunni given by Cohen is one who will not support terror attacks on Shi'ahs or Sufis, or on Christians, Jews, or Hindus. In addition, Cohen also defines moderate Muslims as those who respect "the right to interpret the Qur'an, to worship Allah in the way they chose, or not to worship and even not to believe". ${ }^{14}$

These criteria are problematic in two ways: first, the right to interpret the Qur'an is not belongs to everyone equally. It is because, like other sciences, science of interpretation (tafsir) is a knowledge discipline that has theory, method and subject matter that should be mastered by one who wants to interpret the Qur'an. Once this discipline of knowledge is mastered one has the right to interpret and deserved the respect from other. Consequently, one has no right to interpret unless he has authority to do so. Without qualification of legal sciences for example one cannot have the right to be a judge; a person who has no economic studies background have no right to make state economic policy etc. Regarding freedom of worship, Islam respect the right to chose either to worship or not to worship, to be Muslim or not to be. But Islam gives no right to everyone to worship Allah in his/her own way. There are preordained ways of worshiping Allah (ritually or socially), and there are matters that are opened for Muslim to make ijtihad (rational interpretation of legal matters).

The foregoing definitions are biased with liberal tendency which are now emulated by the liberal Muslim activists. In this regard Esposito reacted proportionally by saying that the liberal definition may exclude those who are not liberal. It is because if moderate mean to be a liberal reformer or a progressive, it may

${ }^{14}$ Ariel Cohen, "Power or Ideology: What the Islamists Choose will Determine Their Future", The American Journal of Islamic Social Sciences, Volume 22, Issue 3, 2 . 
imply that conservative or traditionalist stance could be excluded as non-moderate. Therefore, moderate in Islam, as in all faith such as Judaism and Christianity, in Esposito's definition refer to the majority or mainstream in Islam that represents a multitude of religious and socioeconomic positions. However, the moderate of the mainstream may have different ways in interpreting and reinterpreting Islam to respond the religious, social, and political realities of their societies and to international affairs. Moderate Muslim, Jews and Christians can hold positions ranging from reform to ultraorthodox and fundamentalist and, at times, can bitterly disagree on theological and social policies (e.g., gay rights, abortion, ordination of women and American foreign and domestic policies). ${ }^{15}$ In response to Ariel Cohen's support to Amina Wadud's leading of a mixed-gender Friday prayer, Esposito asserts:

If a woman leading an official prayer service were a criterion for moderate, then many Christian and Jewish groups, denominations, and their leaders (e.g., the recently deceased Pope John Paul II) would fail the test and not be moderates. ${ }^{16}$

Esposito's idea that the moderate Muslims exists in the mainstream of Muslim community is more cogent and justifiable than Andrew idea. The rationale is clearly explicable that if moderate Muslim is defined as one who has secular worldview and against shariah, it would imply that those who do not exercise basic Islamic norm and morality could be regarded as moderate, whereas the Muslims mainstream are carrying out shariah and Islamic norm but they are remain moderate.

${ }^{15}$ John L. Esposito, "Moderate Muslims: A Mainstream of Modernists, Islamists, Conservatives, and Traditionalists", The American Journal of Islamic Social Sciences, Volume 22, Issue 3, 12-13.

${ }^{16}$ John L. Esposito, "The Clash of Ignorance: the War on Terror Must Not Compromise Muslim Rights", The American Journal of Islamic Social Sciences, Volume 22, Issue 3, 56. 
The third category of moderate Muslim definition is of Muslim scholars. The term moderate may be parallel with wasatiyah in Islamic intellectual tradition. Wasatiyah is derived from the words wasat that means being in the middle of thing or between two extremes or moderate in everything between good and bad. ${ }^{17}$ If we refer to the Arab tradition the term wasatiyah means righteousness, just and goodness, esteem, high position. Those people from respectful family were called wasat fi qaumihi. ${ }^{18}$ However, the term is originally of the Qur'anic assertion:

Thus, have We made of you an Ummah of justly balanced (ummatan wasatan), that ye might be witnesses over the nations, and the Messenger a witness over yourselves. (Q.S. al-Baqarah [2]: 143)

In this verse, Allah swt. explains that the Islamic people are ummatan wasatan. There are numerous interpretations by the religious scholars (mufassirin) regarding the term wasatan, at-Tabari, for example interpreted the term wasatan as "the best, the fair and the chosen that are different from the extreme attitude of Jew and the Christians". ${ }^{19}$ Ibn Kathir also interpreted it as the best, most humble and being fair. ${ }^{20}$ The most comprehensive interpretation is that of Fakhr ad-Din ar-Razi who defines wasatiyah into four meanings: First, fairness meaning not to take sides between two conflicting parties or two extreme ends.

${ }^{17}$ Abu al-Husayn Ahmad Fariz bin Zakariya, Mu'jam Maqayis al-Lughah, Juz 2, ed. 'Abd as-Salam Muhammad Harun (Kairo: Maktabat al-Habikhi, 1981), v.s. Wasatiyah.

${ }^{18}$ Rania Muhammad Aziz Nadami, "al-Wasatiyyah fi at-Tarafiyyah bayn alMashru' wa al-Mamnu"', Journal of Department of Islamic and Arabic Studies for Girl, Volume 3, Issue 26, 10.

${ }^{19}$ Abi Ja'far Muhammad bin Jarir at-Tabari, Tafsir at-Tabari al-Musamma Jami' alBayan fi Ta'wil al-Qur'an (Beirut, Lubnan: Dar al-Kutub al-'Ilmiyyah, 1992), Vol. 2, 8-10.

${ }^{20}$ Al-Hafiz Abi al-Fida' Isma'il Ibnu Kathir, Tafsir Al-Qur'an Al-Ažim (Beirut, Lubnan: Dar al-Ma'rifah, 1992), Vol. 1, 196-197. 
Second, something that is the best. Third, the most humble and perfect. Fourth, is not to be extreme in religious matters. ${ }^{21}$

In line with the above Qur'anic interpretation Bedoui Abdelmajid define wasatiyyah as moderate in exercising religious belief, in the acts of devotion, in social intercourse, in custom, in the modern Islamic thought and in the actual life. ${ }^{22}$ This implies that the Islamic definition of moderation is not exactly the same as those of Western scholars. Be that as it may, from the perspective of Islam some aspects of definitions by non-Muslim scholars might be in line with Islamic teaching, whereas some other aspects a might be not. Therefore, Muqtedar Khan tries to combine and summarize the Western standard and the Islamic one. The characteristics of moderate Muslim are:

.... reflective, self-critical, pro-democracy and pro-human rights, and closet secularists. .... cherishes freedom of thought while recognizing the existential necessity of faith; aspires for change, but through the power of mind and not through planting mines; aspires for a society-a city of virtue-that will treat all people with dignity and respect (Qur'an 17:70). There will be no room for political or normative intimidation (Qur'an 2:256). Individuals will aspire to live an ethical life for they recognize its desirability. Communities will compete in doing good, and polities will seek to encourage good and forbid evil (Qur'an 5:48 and 3:110). They believe that internalizing Islam's message can bring about the social transformation necessary for establishing the virtuous city. The Qur'an advocates moderation (Qur'an 2:143) and extols the virtues of the straight path (Qur'an 1:1-7). For moderate Muslims,

${ }^{21}$ Fakhr ad-Din ar-Razi, at-Tafsir al-Kabir aw Mafatih al-Ghayb (Beirut, Lubnan: Dar al-Kutub al-'Ilmiyyah, 1990), Vol. 2, 88-89.

${ }^{22}$ Bedoui Abdelmajid, "Islam and Moderation", a paper presented at Symposium Islam in Asia, Revisiting the Socio-Political Dimension of Islam, held The Japan Institute of International Affairs, with co-ordination from Institute of Islamic Understanding Malaysia, Tokyo, October 15-16, 2008. 
the middle ground, the common humanity of all, is the straightest path. ${ }^{23}$

To clarify the moderate identity among the Muslims, Khan compares it with the militant Muslims. The point of comparison is in methodological orientation and in the primordial normative preferences that shape their interpretation of Islam. For moderate Muslims, ijtihad is the preferred method of choice for sociopolitical change and military jihad is the last option. For militant Muslims, military jihad is the first option and jitihad is not an option at all. Ijtihad, narrowly understood, is a juristic tool that allows independent reasoning to articulate Islamic law on issues where textual sources are silent. The unstated assumption is that when the texts have spoken, reason must be silent. But, increasingly, moderate Muslim intellectuals see ijtihad as the spirit of Islamic thought that is necessary for the vitality of Islamic ideas and Islamic civilization. Without ijtibad, Islamic thought and Islamic civilization fall into decay. Another point of different between militant and moderate Muslim is that the former in the Muslim world is a small minority in the margins, whereas the moderate is vast majority. This is empirically true everywhere, even in Iraq, where terrorism and insurgency is practiced by a small minority of the smallest minority (Sunnis). In this point Khan agree with John Esposito that the mainstream Islamists and traditional Muslims are moderate. ${ }^{24}$

${ }^{23}$ Secularism in Khan understanding is American in nature; that is, they believe in the separation of church and state, but not like the French, who oppose the exile of religion from the public sphere. M.A. Muqtedar Khan, "Islamic Democracy and Moderate Muslims: the Straight Path Runs through the Middle", The American Journal of Islamic Social Sciences, Volume 22, Issue 3, 40-41; see also http:/ / www.ijtihad.org/moderatemuslims.htm, seen on October 18,2010

${ }^{24}$ Muqtedar Khan, "Moderate Muslims Are the Key to the Future of Islam and American-Muslim Relations", The American Journal of Islamic 
From the foregoing definitions, either anti-Islamic, Western or the Islamic one we may come up with one comprehensive and acceptable definition that consists of criteria that may stem from the Western observers but generally could be acceptable in Islam or from Islamic teaching that might be consonant with the contemporary world. Those criteria can be grouped into non-violence, sociopolitical and mental criteria. The non-violence criteria are: (a) against terrorism; (b) a non-violent approach to politics or no political intimidation; (c) participating in democratic process; (d) using no compulsion in religion. The sociopolitical criteria are: (a) pro-universal human right; (b) respect diversity; (c) tolerance; (d) equitable treatment of women; (e) seek to emphasize common ground with other faiths; (f) seek Islamic political and social values that are consonant with the idea of the rest of the contemporary world; (g) respect other religious adherence and belief; (h) treat all people with dignity and respect. The mental criteria are: (a) open to the idea of evolutionary change but through the power of mind or supporting ijtihad; (b) pro Islamic reform; (c) freedom of thought while recognizing the existential necessity of faith.

Having clarified the definition of moderate Muslim, we shall now appraise to what extent the thought of Indonesian Muslims matched with the position those general definitions either in politic or religious education.

\section{Muslim Organizations}

The salient feature of Indonesian Muslims organizations could be traced from the role the two largest mass-based Muslim organizations in the World: Muhammadiyah and Nahdlatul Ulama (Revival of Muslim Scholars). These two

Social Sciences, Volume 22, Issue 3, 72-73; Khan mentions that John Esposito also includes the Islamists and traditional Muslims in his definition of moderate Muslim. 
massive socio-religious organization together represent over 75 million Indonesian Muslims, comprise of vast interconnected network of women, students, laborers, teachers, Islamic boarding school (pesantren), hospitals, school, universities, legal aid agencies, newspapers, and many more affiliated units, reaching down to the village level across the country.

Muhammadiyah, is largest Muslim organization founded in 1912, four years earlier than Nahdlatul Ulama. It was established as an Islamic NGO and a modern Islamic organization, with special focus on public services, training and education. Its main concern and target has been community development. From the era of Dutch colonialism to the period of national independence consisting of three subsequent regimes, namely the Old Order (1945-1965), the New Order (1966-1965), and the Order of Reformation after the fall of Soeharto in 1998, the Muhammadiyah has firmly maintained the original vision of the organization and consistently pursued this basic concern. The fundamental mission of this organization is social service, the actual activity of which are the social and cultural sphere, such as education, economy, health care, poor and orphan care and so forth.

The serious and consistent commitment of the Muhammadiyah to empower society and to promote community development can be seen nationally by the reluctant and unwillingness of its central board to change its social and cultural orientation to a political one, an idea that has surfaced in public discussion from time to time. Despite changes in political order in Indonesian politic and regimes, Muhammadiyah had consistently played its pivotal role in promoting and enhancing the idea of civil society in Islamic sense. Eschewing the political orientation but 
without abandoning political participation, Muhammadiyah consistently build a community independently from the hegemony of state regardless of the nature of the ruling government. ${ }^{25}$ So, the moderate stance of Muhammadiyah in politics is manifest, since the members of Muhammadiyah have no problem with democratic system and even participate in democratic process. No record of political intimidation or violent approach to politics. In 2015 this organization had successfully sued the government for amending the constitution of natural resources without any violent or intimidation. In term of religious preaching there were no records of compulsion in religion. A respect to other religious adherence and belief is proven by the absent of conflict between Muhammadiyah and other religious adherence.

If the Western moderate criteria necessitate the equitable treatment of women, the Muhammadiyah organization from the very beginning concern with the empowerment of women. In 1917 this organization established its women wings named Aisyiah with the objective of empowering women for the betterment of the society. For the youth, the organization also established girl section named Nasyiatul Aisyiyah. In the educational field it runs 13 institute and universities, 23.772 primary and secondary schools, and more than 7000 play groups and nursery schools. In the field of public health it runs 15 general hospitals, 7 children hospitals, 71 clinics for mother and children, 18 pharmacies and the likes. In economic sector it has 568 cooperation units. However, this empowerment is based on Islamic teaching and no idea of feminism and gender equality whatsoever.

${ }^{25}$ M. Amin Abdullah, "Muhammadiyah's Experience in Promoting Civil Society on the Eve of the 21th Century", in Mitsuo Nakamura, Sharon Siddique, and Omar Farouk Bajunid, Islam and Civil Society in Southeast Asia (Singapore: ISEAS, 2001), 44-45. 
In short, Muhamadiyah is reformer organization of Islam and much concern with human resource development. Therefore it is not surprising that now Muhammadiyah has not less than 9.527 educational institutions of various types including universities, and 3.775 health and welfare-related centers. In this regard, Muhammadiyah has no problem with tolerance, respect of diversity and human right.

Nahdlatul Ulama (NU) is the large mass-based organizations. Founded in 1926, and today it has-as they claims-approximately 50 million members. It runs formal religious school and traditional schools (pesantren), health centre and community associations throughout the country. In $2006 \mathrm{NU}$ described its vision as being 'the establishment of social justices and democratic order, based on the Islamic doctrine of ablussunnah wal jama'ah, and its mission as being to influence the legal system and promote policies that ensure social justice and democratic order, as well as community empowerment. The official PBNU website states that NU's aim is to institute the teaching of Islam, based on ablussunnah wal jama'ah, through society, within the framework of the Unitary State of the Republic of Indonesia. ${ }^{26}$

With respect to the moderate criteria such as a non-violent approach to politics or no political intimidation and participating in democratic process, the traditional pesantren in particular and Nahdlatul Ulama in general are not against those criteria. However, in the last decade pesantren were dubbed with various epithets such as the breeding grounds for terrorism. "Terrorist-linked pesantren" 28 , or "Indonesia's fundamentalist pesantren", ${ }^{29}$ and "a training

${ }^{26}$ http://www.nu.or.id.

${ }^{27}$ Peter Jean, "Australia May Fight Terror Through Indonesian Schools", Australian Associated Press General News, October 5, 2003.

${ }^{28}$ Sian Powell and Sandra Nahdar, "Warning on Closing Islamic schools", The Australian, October 4, 2003.

${ }^{29}$ Piers Akerman, "Time to Remember Bali's Ground Zero", Sunday Telegraph, October 5, 2003. 
center of terrorist'. Paul Wolfowitz, former US Ambassador for Indonesia, and President of World Bank, for example, states erroneously that:

What they're taught there (in pesantren) is not real learning. It's not the tools for coping with the modern world. It's the tools that turn them into terrorists. ${ }^{30}$

It seems that to infer that the whole pondok education institution in Indonesia is the training center for terrorist is inappropriate. The inference based on single case of pesantren out of thousand pesantren is illogical, since the number of pondok which are accused of being involved in the activities of terrorism are less than dozen, while the whole number of pesantren in Indonesia is no less than $24.000 .{ }^{31}$ So to extrapolate the existence of terrorist from small number of pesantren to all other Indonesian pesantrens is considerably misleading. In fact, the pesantren and Nahdlatul Ulama play no significant role in the individual act of terrorism.

With regard to political affairs, the pesantren support the democratic system of the government, voluntarily vote in general election, follow the government programs and obey the rules and regulations imposed by the government. So, politically, the member or the organization of Nahdlatul Ulama, could be regarded as moderate, since there is no record of political intimidation or violent approach to politics. In preaching Islam Nahdlatul Ulama has no records of compulsion in religion, and no conflict with other religious adherence and belief. Realizing the Indonesian motto Bhinneka Tunggal Ika (unity in diversity) the pesantren

${ }^{30}$ C. Duncan Graham, "Confronting Australian Smugness", The Jakarta Post, July 14, 2005.

${ }^{31}$ See "Indonesia Backgrounder: How The Jemaah Islamiyah Terrorist Network Operates", ICG Asia Report, Number 43, December 1, 2002; and "Jemaah Islamiyah in South East Asia: Damaged but Still Dangerous”, ICG Asia Report, Number 63, August 26, 2003, 26-29. 
and its graduates commits to respect religious, race and cultural diversities. Pesantren is not like a pressure group that forces its aspiration by using violence or other means that justify end; it is abode of peace, a place for producing pious men and women.

Similar case with Muhammadiyah organization, Nahdlatul Ulama is in support of universal human right and has equitable treatment of women. Therefore, for the empowerment of women in 1950 it established a women wing called Muslimat with its young section named Fatayat. Now it has 15 million members, 400 branches throughout Indonesia and abroad. ${ }^{32}$ In economic sector tt has 17 outlet for agriculture, 131 economics unit of cooperation. In the field of education it run 4.657 play groups, 3.800 women religious study groups (majelis taklim); 1.003 orphanages, 58 hospitals and public health services for mother and children, 11 training centre for jobless, 146 training centre for hajj. ${ }^{33}$

With respect to its attitude towards non-Muslim or religious adherence Nahdlatul Ulama has no record of intolerance and conflict. It has an experience of living in pluralistic society and religions and treat all people with dignity and respect. In term of social change this organization has its own tradition for Problem Solving Forum called Bahtsul Masa'il in which ijtihad is well exercised.

\section{Indonesian Muslims' Education System}

The renowned Muslim education system is pesantren or pondok pesantren that uniquely consists generally of five elements. The renowned five elements of the system are: (a) scholar (kiai); (b) mosque (masjid); (c) student (santri); (d) dormintory (pondok); (e) classical book named kitab kuning

\footnotetext{
${ }^{32} \mathrm{http}: / /$ www.pcfatayatnujombang.or.id/page/sejarah-fatayat-nu.

${ }^{33}$ http://www.nu.or.id.
} 
(yellow book). ${ }^{34}$ The element of kiai is considerably important in pondok pesantren as a central figure who has significant authority in certain discipline of religious knowledge and in handling so many problems concerning the pondok affairs as well as the possessor of charisma to whom all inhabitant of pondok highly respect him..$^{35}$ The mosques that exist in all pondok pesantren are the centre for all activities. The centrality of mosques in the history of Islamic education is manifest, since it existed long before the madrasah institutions were established. The student is another important factor or element in the pondok pesantren. The most substantive element of pondok pesantren is its educational activities. For the traditional system of pondok pesantren the main curricular activities is reading the classical texts. The classical textbooks consist generally of Islamic sciences and Arabic language. ${ }^{36}$ Dhofier assert that "in the past, the teaching of classical books of Islam ... is the only formal teaching imparted in milieu of pondok pesantren". However, at present most of pesantren take general sciences as an important part of pesantren education system, yet the teaching of classical books is highly recognized. ${ }^{37}$

The pesantren curriculum in general is very similar to that of other traditional education institutions in the Muslim world, especially where the Syafi'i school is combined with a few basic compendia of Asy'ari doctrine and enriched with the sufi traditions. The curriculum consist of only religious subjects. The well known traditional curriculum is divided

${ }^{34}$ Farid Hasyim, "Visi Pondok Pesantren dalam Pengembangan SDM: Studi Kasus di Pondok pesantren Mahasiswa al-Hikam", Thesis, Program Pascasarjana Universitas Muhammadiyah Malang (UMM), 1998, 39. However, by the emergence of modern system of pesantren the element of classical book (kitab kuning) were replaced by more general subjects of Islamic studies that include general sciences.

${ }^{35}$ Hasbullah, Sejarah Pendidikan Islam di Indonesia:Lintasan Sejarah Pertumbuban dan Perkembangan (Jakarta: Raja Grafindo Persada, 1999), 144.

${ }^{36}$ Zamakhsyari Dhofier, Tradisi Pesantren: Studi Tentang Pandangan Hidup Kyai (Jakarta: LP3ES, 1985), 50.

${ }^{37}$ Hasbullah, Sejarah Pendidikan, 144. 
into three levels: The basic level consists of theology, Islamic jurisprudence, ethic, method of reading Qur'an. The secondary level consists of theology, Islamic jurisprudence, ethic of learning, Arabic grammar, method of reading the Qur'an. The third level contains theology, jurisprudence, ethic and sufism, Islamic legal philosophy, Qur'anic interpretation, science of hadith, Arabic grammar, logic (only at certain pondok pesantren). ${ }^{38}$ The above model and curriculum of pesantren has been practiced for long time ago with some modifications and improvements.

The method of teaching that generally consisted of two major method of teaching: the individual method usually called bandongan or collective method usually named wetonan. In the former method every student has the opportunity to learn directly from the master teacher or his assistance, but the method is employed usually for those who already master reading the Qur'an. ${ }^{39}$ Another method is called sorogan, that is a method usually employed for new students who need individual assistance. In all those method, the master teacher or his assistance take important and dominant role in the teaching learning process. The method of teaching is quite simple where a number of students listen to

${ }^{38}$ Martin van Bruinessen, "Kitab Kuning: Books in Arabic Script Used in the Pesantren Milieu", Bijdragen tot de Taal-, Land-, en Volkenkunde 146 (1990), 226-269. See also http://www.let.uu.nl/ martin.vanbruinessen /personal/ publications/kitab_kuning.htm.

${ }^{39}$ Zamakhsyari Dhofier, Tradisi Pesantren, 28. The distribution of subjects taught at the Pesantren based on the texts can be categorized into: jurisprudence (fiqh) $20 \%$; doctrine (aqidah, ushul ad-din) $17 \%$; traditional Arabic grammar (Nabw, Sharf, Balaghah) $12 \%$; hadith collections 8\%; mysticism (tasawnf, thariqah) $7 \%$; morality (akblaq) $6 \%$; collections of prayers and invocations, (doa, wird, mujarobat) 5\%; and texts in praise of the prophets and saints (qishas al-anbiya', mawlid, manaqib, etc.) 6\%. Martin van Bruinessen, "Kitab Kuning: Books in Arabic Script Used in the Pesantren Milieu", Bijdragen tot de Taal-, Land-, en Volkenkunde 146 (1990), 226-269. See also http://www.let.uu.nl/ martin. vanbruinessen/personal/publications/kitab_kuning.htm. 
a teacher who read and translate the classical Arabic books into local languages such as Java, Sunda, Madura and the likes. ${ }^{40}$

Along with the increase of the number of pondok pesantren institution there were trends in some pondoks to adopt modern system of education. This trend is evident from the increase of the number of modern pondokpesantren system in 2008 alluded above (62\%). However, the modernization in this sense does not necessarily imply Westernization or secularization. Modernization here is meant adoption of new method of teaching learning in holistic fashion. There were at least two types of pondok pesantren modernization, one was the adoption of school system separately from pondok pesantren system, like what was introduced by Wahid Hasyim at his Pondok of Tebuireng, Jombang.

Another model of modernization was the integration of pesantren system with that of madrasah or school system. This type of modernization was initiated by K.H. Imam Zarkasyi and his two brothers K.H. Ahmad Sahal and K.H. Zainuddin Fannani at Darussalam Gontor. The basic consideration to integrate madrasah system into pesantren system was based on his observation that-on the one hand-madrasah is good system for formal education but not for non-formal and informal education. Students may learn well in the class but what happen outside the class was beyond the system. The madrasah is precisely like the modern school system but is not sufficient to inculcate other Islamic teachings that are not covered by the madrasah curriculum. On the other hand, the pesantren system is ideal system for nonformal and informal education for it has good tradition of boarding system. K.H. Imam Zarkasyi adopted the positive aspects of both the madrasab and the pesantren system and

${ }^{40}$ Ibid. 
assimilated them within his own system. The nature of the new system is discernable from his statement below:

This pondok (pesantren) is an Islamic educational institution like any other institution. The difference is only in its teaching method. We use modern teaching method but do not teach something new in religion. This pondok (pesantren) is a waqf for the Muslim ummah and is not the property of the kiai (headmaster of pesantren) anymore. This pondok pesantren has no inclination to any political parties, therefore its motto is Berdiri di atas dan untuk Semua Golongan (Stand above and for all Groups). Its educational goal is to produce a Muslim who has noble character, sound body, broad knowledge, and independent mind. ${ }^{41}$

From the foregoing statement and the fact that can be observed we may infer that the modernization of pondok pesantren system of education consisted of the modernization of curriculum, education system, teaching methodology and institution. ${ }^{42}$

Back to the issue of moderation, the traditional and modern system of pesantren has similarly produced human capitals that nationally played pivotal role on the building Indonesian nation prior to and after its independence. They are spread over diverse field of works not necessarily in religious activities or institutions. It goes without saying that student of pondok and its graduates had been and are one of the most important groups in Indonesia. In fact, numbers of Indonesian political leaders are graduated from pesantren. The national figures during the Indonesian independence such as Wahid Hasyim, Idham Khalid, Wahab Hasbullah and others were the graduates of pesantren. After the independence

${ }^{41}$ Imam Zarkasyi, "Pidato pada Resepsi Kesyukuran Setengah Abad Pondok Modern Darussalam Gontor dan Peresmian Masjid Jami' Gontor”, unpublished text of speech, 1976.

${ }^{42}$ Abdullah Syukri Zarkasyi, Gontor dan Pembaharuan Pendidikan Pesantren (Jakarta: RajaGrafindo Persada, 2005), 12-14. 
numbers of national figure such as Abdurrahman Wahid, Syukri Ghazali, Subchan ZA, Saifuddin Zuhri, Hasyim Muzadi, Din Syamsuddin, Hidayat Nur Wahid, Saleh al-Jufri are the graduate of pesantren. Certainly they are moderate in the real sense of the words.

These two organizations are powerful, well entrenched, and moderate grassroots operations, promote Islamic values, traditions and practices, and in some cases may advocate Islamic law, however, they are committed to working within the law, and as part of the political system to advance their goals. Individuals and some groups or factions within these organizations were in fact instrumental in helping democracy bloom in 1998 and afterwards. Both NU and Muhammadiyah have conservative elements within them. Yet, within Muhammadiyah and NU there are a variety of other associations that are working on developing democratic values in religious schools, promoting dialogue and understanding about the role of Islam in life and politics. Some leaders of these organizations support the idea of enhancing "democracy through mainstream Islamic institutions, building Islamic social concern, democracy, plurality and tolerance". ${ }^{43}$ Even though the two organizations are not involved in political parties, their political aspirations were accommodated in certain political party. NU provides the support base for the National Awakening Party (Partai Kebangkitan Bangsa, PKB), and the National Unity Party (Partai Persatuan Pembanguan, PPP), while the Muhammadiyah support the National Mandate Party (Partai Amanat Nasional, PAN), Amien Rais' party, and the Crescent and Star Party (PBB).

${ }^{43}$ Azyumardi Azra, "Radical and Mainstream Islam: New Dynamics in Indonesia", Theodore Friend (ed.) Religion and Religiosity in the Philippines and Indonesia: Essays on State, Society, and Public Creeds (n.p.: Bookings Institute Press, 2000), 25-26. 
In short the two organizations have moderate position having no indication of supporting violence approach in its social reform. Politically, they respect diversity, tolerance, open to the idea of change through ijtihad, respect people of other religions, and admit democracy and nation state of Indonesia. Religiously, they are neither conservative nor liberal in Western sense, but moderate and open minded in Islamic sense. The moderate position of these two mass organizations is concisely stated by Syafi'i Ma'arif, former Chairman of Muhammadiyah, that "As long as the two mainstream groups, Nahdlatul Ulama and Muhammadiyah, adhere to moderate, liberal Islam, fundamentalism should be impossible.... Actually, the militant movements, which influence young people looking for identity, can only be fought by creating a normal situation, with justice. So fundamentalism could take root unless we solve these problems". ${ }^{44}$ So, undoubtedly the acceptable criteria of moderate Muslim posited above are already embedded in these two organizations. This is the proof of what has been alluded by Esposito that the Muslim mainstream is moderate.

\section{Conclusion}

The foregoing appraisal of Indonesian moderate position based on the general and objective definition suggests that the majority of Indonesian Muslims, including religious education institution, religious mass-based organization and Muslim political parties, are moderate Muslims. They continue to be devout Muslims, commit to their faith and exercise their religious injunction (shari'a) in their social, political and educational activities. Emulating their predecessors of early Muslim generation whose activities were driven by piety and faith but still able to build great flourishing civilizations that was worthwhile for humanity, the Indonesian Muslims remain

${ }^{44}$ Interview in Van Zorge Report, "Islam is Only Being Used as a Political Commodity", December 2000. 
open minded and willing to collaborate with other religious adherent, nation and other group for better spiritual, mental and material life. They participate in democracy and support the principle of human right under the dictate of universal Islamic tenets, without rigidly upholding specific system and structure of government. Therefore, they cannot be classified into liberal for their commitment to Islamic values and their critical stance of Western values incompatible with Islam as well as unjust political policies towards Islamic countries. However, they also reject radical Islamic groups and uncompromised demand of the establishment of an Islamic state based on the shari'a. The radical Islamic groups in Indonesia seems to be a relatively marginal phenomenon and it will be continuously kept on the fringes of society and remain a small minority. 


\section{REFERENCES}

Abdelmajid, Bedoui. "Islam and Moderation", a paper presented at Symposium Islam in Asia, Revisiting the Socio-Political Dimension of Islam, held The Japan Institute of International Affairs, with co-ordination from Institute of Islamic Understanding Malaysia, Tokyo, October 15-16, 2008.

Abdullah, M. Amin. "Muhammadiyah's Experience in Promoting Civil Society on the Eve of the 21th Century", Mitsuo Nakamura, Sharon Siddique, and Omar Farouk Bajunid. Islam and Civil Society in Southeast Asia. Singapore: ISEAS, 2001.

Akerman, Piers. "Time to Remember Bali's Ground Zero", Sunday Telegraph, October 5, 2003.

Azra, Azyumardi. "Radical and Mainstream Islam: New

Dynamics in Indonesia", Theodore Friend (ed.) Religion and Religiosity in the Philippines and Indonesia: Essays on State, Society, and Public Creeds. n.p.: Bookings Institute Press, 2000.

Bruinessen, Martin van. "Kitab Kuning: Books in Arabic Script Used in the Pesantren Milieu", Bijdragen tot de Taal-, Land-, en Volkenkunde 146 (1990).

Cohen, Ariel. "Power or Ideology: What the Islamists Choose will Determine Their Future", The American Journal of Islamic Social Sciences, Volume 22, Issue 3, 2005.

Dhofier, Zamakhsyari. Tradisi Pesantren: Studi Tentang Pandangan Hidup Kyai. Jakarta: LP3ES, 1985.

Esposito, John L. (ed.), Islam in Asia: Religion, Politic, and Society. New York-Oxford: Oxford University Press, 1987. 
Esposito, John L. "Moderate Muslims: a Mainstream of Modernists, Islamists, Conservatives, and Traditionalists", The American Journal of Islamic Social Sciences, Volume 22, Issue 3, Summer 2005.

- "The Clash of Ignorance: the War on Terror Must Not Compromise Muslim Rights", The American Journal of Islamic Social Sciences, Volume 22, Issue 3, 2005.

Fuller, Graham E. "Freedom and Security: Necessary Conditions for Moderation", The American Journal of Islamic Social Sciences, Volume 22, Issue 3, 2005.

Graham, C. Duncan. "Confronting Australian Smugness", The Jakarta Post, July 14, 2005.

Hasbullah. Sejarah Pendidikan Islam di Indonesia:Lintasan Sejarah Pertumbuban dan Perkembangan. Jakarta: Raja Grafindo Persada, 1999.

Hasyim, Farid. "Visi Pondok Pesantren dalam Pengembangan SDM: Studi Kasus di Pondok pesantren Mahasiswa al-Hikam", Thesis, Program Pascasarjana Universitas Muhammadiyah Malang (UMM), 1998.

Ibnu Kathir, al-Hafiz Abi al-Fida' Isma'il. Tafsir Al-Qur'an Al- 'Azim. Beirut, Lubnan: Dar al-Ma'rifah, 1992.

"Indonesia Backgrounder: How The Jemaah Islamiyah Terrorist Network Operates", ICG Asia Report, Number 43, December 1, 2002.

Interview in Van Zorge Report, "Islam is Only Being Used as a Political Commodity", December 2000.

Jan, Abid Ullah. "Moderate Islam: a Product of American Extremism", The American Journal of Islamic Social Sciences, Volume 22, Issue 3, 2005. 
Jean, Peter. "Australia May Fight Terror Through Indonesian Schools", Australian Associated Press General News, October 5, 2003.

"Jemaah Islamiyah in South East Asia: Damaged but Still Dangerous", ICG Asia Report, Number 63, August 26, 2003.

Khan, M.A. Muqtedar. "Islamic Democracy and Moderate Muslims: The Straight Path Runs through the Middle", The American Journal of Islamic Social Sciences, Volume 22, Issue 3, Summer 2005.

Khan, Muqtedar. "Moderate Muslims Are the Key to the Future of Islam and American-Muslim Relations", The American Journal of Islamic Social Sciences, Volume 22, Issue 3, 2005.

McCarthy, Andrew. "Inventing Moderate Islam [incl. John Esposito]", National Review Online, August 24, 2010.

Nadami, Rania Muhammad Aziz. "al-Wasatiyyah fi atTarafiyyah bayn al-Mashru' wa al-Mamnu", Journal of Department of Islamic and Arabic Studies for Girl, Volume 3, Issue 26, 2005.

Powell, Sian and Sandra Nahdar, "Warning on Closing Islamic schools", The Australian, October 4, 2003.

ar-Razi, Fakhr ad-Din. at-Tafsir al-Kabir aw Mafatih al-Ghayb. Beirut, Lubnan: Dar al-Kutub al-'Tlmiyyah, 1990.

Safi, Louay. "Reflections on Ijtihad and Moderate Islam", The American Journal of Islamic Social Sciences, Volume 22, Issue 3, Summer 2005.

at-Tabari, Abi Ja'far Muhammad bin Jarir. Tafsir at-Tabari al-Musamma Jami' al-Bayan fi Ta'wil al-Qur'an. Beirut, Lubnan: Dar al-Kutub al-'Tlmiyyah, 1992. 
Zakariya, Abu al-Husayn Ahmad Fariz bin. Mujam Maqayis al-Lughah, Juz 2, ed. 'Abd as-Salam Muhammad Harun. Kairo: Maktabat al-Habikhi, 1981.

Zarkasyi, Abdullah Syukri. Gontor dan Pembaharuan Pendidikan Pesantren. Jakarta: RajaGrafindo Persada, 2005.

Zarkasyi, Imam. "Pidato pada Resepsi Kesyukuran Setengah Abad Pondok Modern Darussalam Gontor dan Peresmian Masjid Jami' Gontor", unpublished text of speech, 1976. 